\title{
Bibliometric review about eco-cites and urban sustainable development: trend topics
}

\author{
Margarida Rodrigues ${ }^{1} \cdot$ Mário Franco ${ }^{2}$
}

Received: 17 September 2020 / Accepted: 25 November 2021 / Published online: 6 January 2022

(c) The Author(s), under exclusive licence to Springer Nature B.V. 2021

\begin{abstract}
The world is undergoing exponential urbanization, with consequences for society in general, both for cities and people, with serious economic, social and environmental implications. Therefore, it is crucial to reconsider urban models of cities, to ensure global, longterm sustainability. Numerous researchers have argued that one of these models involves eco-city projects, and this study aims to carry out a systematic review of the literature on this topic, through bibliometrics. To do so, the Smarter, Prisma and Vantage Point methods were used, reflecting the originality of the study. The results obtained show that China has aroused researchers' interest regarding its eco-city projects, with most studies being empirical, and so this study complements them. The main contribution of this research lies in identifying the keywords most used by authors, these being eco-cities, sustainable cities (cluster 1) and eco-cities, China, sustainable urban development and eco-cycle model (cluster 2). Finally, implications for theory and practice are presented, together with suggestions for future research.
\end{abstract}

Keywords Eco-cities · Urban sustainable development · Bibliometric · Trend topics

\section{Introduction}

The world's population is due to growth by 2 billion in the next 30 years, from the current 7,7 billion people to 9,7 billion in 2050, according to the United Nations-World Population Prospects 2019 (UN, 2019). In Europe, urban areas account for around 67\% of the population of the European Union, representing approximately $80 \%$ of the energy used and contributing 85\% to Europe's Gross Domestic Product (UE, 2021). This means that $75 \%$ of Europe's population live in urban areas, creating environmental challenges, and it

Mário Franco

mfranco@ubi.pt

Margarida Rodrigues

mmmrodrigues@sapo.pt

1 CEFAGE-UBI Research Center, Instituto de Estudos Superiores de Fafe, Universidade da Beira Interior, Estrada do Sineiro, 6200-209 Covilhã, Portugal

2 Department of Management and Economics, CEFAGE-UBI Research Center, Universidade da Beira Interior, Estrada do Sineiro, 6200-209 Covilhã, Portugal 
is important to find the right balance between density, compactness and quality of life in a healthy urban environment (EEE, 2017). The exponential growth of the urban population associated with greenhouse gas emissions suggests that including sustainability criteria in this process of urban growth is one of the main challenges of this century (Alberti, 2008).

In this scenario, numerous typologies of cities emerge, such as green cities, digital cities, information cities, knowledge cities, resilient cities, low-carbon cities and inhabitable cities, in addition to low-carbon eco-cities and ubiquitous eco-cities (Hart, 2007; Joss et al., 2013), sustainable cities, eco-cities, u-eco cities, eco-friendly cities (Shwayri, 2013), creative cities and smart cities (Visser, 2019). However, all these city concepts promote flexible, entrepreneurial economies, improved mobility through information and communication technology (ICT) infrastructure, participative, transparent governance, a clean sustainable environment, high levels of culture and education and creative, tolerant people (Vanolo, 2014). Moreover, Shwayri (2013, p. 41) argued that all this typology of cities is stimulated by the main objective of "combating global climate change and increased urbanization" but warned that this implies constructing cities from scratch. On the other hand, there are case studies on specific cities, such as the case of Kutahya, where it was concluded that green spaces are a pathway to sustainability (Cetin, 2015b), of Cide on how its coastline is important for the quality of life (Cetin, 2016) and of Pompeipolis, with its ancient karst characteristics that should be seen as an opportunity for sustainability (Cetin, 2015a).

In the extensive literature on various typologies of cities, the concept of the eco-city stands out, and this has been discussed since the 1970s (Miao \& Lang, 2015). In the last twenty years, this has aroused the interest of academics, town planners, environmentalists and non-profit organizations, the World Bank and the United Nations (e.g. Moffatt et al., 2012; Register, 2006). The eco-city concept was popularized by Register (1987, 2006), who defined this as the reconstruction of cities and towns based on ecological principles for long-term sustainability, cultural vitality and a healthy biosphere, as well as producing a healthy and potentially happy future. In the following decades, this definition was complemented with constructs originating in different domains (e.g. ecology, technology, green movement, low-carbon sustainability) (Li \& Qiu, 2015). So the definition of eco-cities is seen to be surrounded by complexity, as it involves principles, models, techniques (Li \& Qiu, 2015), designs, indicators and norms (Bulkeley, 2006; Wong \& Yuen, 2011). Among the numerous definitions, this study adopted the one by Miao and Lang (2015), who postulate that an eco-city is one that minimizes waste and pollution, maximizes energy, transport and renewable resources and provides good-quality public places for its residents, conserving valuable characteristics of local ecology and countryside.

The increased interest in eco-cities has emerged as a consequence of exponential urbanization in developing countries, where it has become urgent to reflect on concerns arising from waste production, the pollution created in cities, the growing costs of energy inputs and other resources for cities (Miao \& Lang, 2015). However, for Caprotti and Romanowicz (2013), the popularity of eco-cities is due to the idea conveyed by authorities of the intention to construct new urban environments to achieve sustainable urban life, by promoting technology and low-carbon industry. Furthermore, recent concern about cities' greenhouse gas emissions and their negative effects on global warming has increased the interest in this topic. All these issues as a whole have convinced cities of the need to increase the energy efficiency of buildings, transport and production systems (Miao \& Lang, 2015). Recently, Vakula et al. (2018) explained that a city's sustainable urban renewal should be carried out holistically, considering quality of life, energy efficiency, environmental concerns and climate change, suggesting some similarities with eco-cities which also aim for 
sustainability (Miao \& Lang, 2015). This line of thought is clear in an empirical study carried out in China by Xie et al. (2020), which concluded that building an eco-city is a high ambition, although necessary if aiming to manage and sustain urban economic growth while considering environmental questions.

The vast literature on topics involving the eco-city concept in its various aspects contains numerous empirical studies about China (e.g. Caprotti \& Romanowicz, 2013; Kang et al., 2019; Liu et al., 2014; Miao \& Lang, 2015; Visser, 2019; Xu, 2017) and a shortage of bibliometric studies on scientific production in the field which would allow conclusions to be drawn about the state of the art. This gap is confirmed by a search on the WoS to identify the number of systematic literature reviews, resulting in six documents between 2016 and 2018. Also the arguments that "eco cites can be seen as a new life style" and that "cities often focus on one or two elements of the paradigm and do not really follow an integrated approach. Secondly, some cities wanted to be eco-cities in the 1990s and are trying to become sponge cities now (Zhuanghe), or smart cities (Shenzhen and Beijing), where they were an eco-city before (both). This has to do with the support received from the national level" (van Dijk \& Zhang, 2019, p. 14). This argument confirms the importance of elaborating a systematic review of the literature on the topic, as highlighted by Wachsmuth et al. (2016), who concluded that cities everywhere are facing unprecedented challenges, with new measures and actions being necessary to achieve broader goals of ecological effectiveness, economic growth and equitable social development, given that they have become one of the largest contributors to greenhouse gas emissions and represent 60 to $80 \%$ of global energy consumption (UN-Habitat, 2016). In addition, Saiu (2017, p. 3) concludes that "the vast body of literature on the projects analyzed can be subdivided into two general categories: single case studies and comparative research. This second category is often focused on the projects carried out in the same geographical, socio-economic and political context", corroborating the justification for carrying out a systematic review of the literature on the topic.

Therefore, this study aims to make a bibliometric analysis of eco-cities and urban sustainable development, so as to identify trend topics, using qualitative (descriptive analysis and Prisma) and quantitative (Smarter and Vantage Point methods) methodology. The study's contribution lies in using an innovative methodology resorting to three methods simultaneously to determine the state of the art of the subject. This will allow the elaboration of a theoretical, conceptual study of which, according to Saiu (2017), there is a shortage in the academic sphere. In addition, the use of the SMARTER method was crucial during the process of deciding the eligibility of the studies, given that its multiple attributes remove the subjectivity inherent in this phase. Furthermore, this method has been little used in research on cities, and this is the innovative character of this study.

\section{Methodology}

\subsection{Bibliometrics}

The systematic literature review requires all the stages followed to be transparent (Briner \& Denyer, 2012) that the collection and systematization of data is specific (Hadengue et al., 2017) and that the results obtained are clear (Briner \& Denyer, 2012). In this context, Tranfield et al. (2003) define the stages to follow in this type of review, i.e. planning the review, locating studies, evaluating their contributions and a summarized analysis of the 
results obtained, which were corroborated by Xiao and Watson (2019). The review presented here followed the bibliometric analysis for scientific mapping of the topic under discussion (Connor \& Voos, 1981; Garfield, 1979; Powell et al., 1996; Quinlan et al., 2008; Wasserman \& Faust, 1994; White \& Griffith, 1981). The systematic review of the literature carried out through bibliometrics aims to identify the most relevant topics, as defended by several authors (e.g. Connor \& Voos, 1981; Howard \& Katherine, 1998; Powell et al., 1996; Quinlan et al., 2008; Wasserman \& Faust, 1994) which assumes scientific documents (Article or review, Proceedings papers and Book Review) as the unit of analysis for grouping them, according to their objectives and issues central banks (Grácio, 2016). Consequently, the operationalization of a bibliometry requires the definition of rigorous steps to follow, which are: a) identification, assessment, content analysis in specific areas (Rowley \& Slack, 2004); b) to assess critical aggregate value by summarizing the literature on the topic studied, identifying gaps and indications for future avenues (Mentzer \& Kahn, 1995); c) guarantee the standardized descriptive analysis (e.g. authors, scientific journals, citations and co-citations, keywords, countries, publications by year) (Prasad \& Tata, 2005; Treinta et al., 2014) and conceptual contents (Seuring \& Müller, 2008); and d) through a methodical and structured research design, defining criteria and keywords and criterion (filtering and eligibility criteria). This means that the bibliometric analysis adopts a mixed methodology to allow assessment of the qualitative and quantitative coverage of a given area of interest (Geaney et al., 2015), as is presented here.

The adoption of the bibliometric methods referred to above is related to the appropriateness of the provision of this systematic review presented here with internal and external validity and, thus, excluding subjectivity. In other words, for the purpose of this study it is crucial to use a mixed approach, by using different qualitative and quantitative methodological procedures, since the qualitative and quantitative methods are complementary to each other and not mutually exclusive (Minayo \& Sanches, 1993; Patton, 1991, 2002). On the other hand, the quantitative method has a strong external validity and a weak external validity, while the qualitative method has a strong internal validity and a little external validity (Serapioni, 2000). In these circumstances, the methods chosen for the elaboration of bibliometrics allow the weak validities to be overcome. This means that SMARTER (quantitative approach), Vantage Point (quantitative approach) and Prisma (qualitative approach-eligibility). In short, this research uses a mixed methodology, given that the eligibility of the documents was obtained by the qualitative PRISMA method and the bibliometry was carried out by the quantitative SMARTER and VANTAGE POINT methods. Additionally, a descriptive and content analysis is presented, for its replicability and valid inferences (Bryman, 2012; Krippendorff, 2012), to complement the results obtained by bibliometrics, endowing this investigation with internal and external validity. This means that the use of different methods of bibliometric analysis allows a holistic combination for the exploration of research trends in a given topic in the literature (Chang et al., 2015). In addition, Pasadeos et al. (1998) advocated that bibliometric methods have become dominant and influential in defining future research on new topics.

Carrying out the bibliometrics involved: (1) the SMARTER method; (2) the PRISMA method; and (3) VANTAGE POINT software. Table 1 summarizes each of these methods.

Therefore, the use of the SMARTER method allowed, objectively, the reduction in the size of the initial database, through multi-criteria attributes (Choulak et al., 2019; Evidence-based et al., 2010; Garza-Reyes, 2015; Rutten-Van Mölken et al., 2018), while the PRISMA method improved the database returned by SMARTER, by applying eligibility criteria. Finally, the use of VANTAGE POINT, developed by Porter and Cunningham (2004), allowed the elaboration of a text-mining, to find patterns and relationships on the 
Table 1 Methods used in the bibliometric analysis

\section{SMARTER method}

Mostly used in studies in the field of medicine (Dolan, 2010), but recently used in the field of management (Marques \& Franco, 2020);

Supported by the multi-attribute utility theory (MAUT), as an analytical instrument linked to the area of decision analysis (Keeney \& Raiffa, 1976);

Use of oscillating weights (SMARTs) and exploratory channels, by using distinct weighting methods, aiming to improve and reduce the load and time of the decision-maker (Edwards \& Barron, 1994);

Use of the multi-criteria method for the decision-making of the American School (MCDM), which postulates a function of multi-attribute utility to represent decision-makers' preferences (Barfod et al., 2016); questions being the comparability of alternatives, transitivity in the relation of preference and indifference; formation of hierarchies and establishing a measure of global merit (Keeney \& Raiffa, 1993);

This method is applied at the stage of selecting scientific documents (Garza-Reyes, 2015), varying according to the criteria adopted (Choulak et al., 2019; Dolan, 2010; Rutten-Van Mölken et al., 2018)

\section{PRISMA method}

A flow diagram (Donato \& Donato, 2019);

Allows definition of eligibility criteria (Adiyarta et al., 2020); These criteria guide data selection (Liberati et al., 2009)

\section{VANTAGE POINT software}

Text-mining tool for discovering knowledge in search results from patent and literature databases (Pradhan, 2016, page 29);

Can produce various networks, co-occurrence analyses, word clouds, descriptive analyses (Pradhan, 2016)

"It allows the user to analyse large volumes of structured text to discover patterns and relationships and quickly address who, what, when, and where" (Cobo et al., 2011, p. 1389)

basis of final documents selected in the $\operatorname{WoS}(n=70)$ (see Fig. 1) and if approaching who, what, when, and where. This software has been used in previous research in mapping scientific analyses (e.g. Morel et al., 2009; Porter \& Youtie, 2009; Shapira et al., 2010).

\subsection{Data collection and search flowchart}

Data were collected online from the WoS database. WoS is widely recognized as a database focused on peer-reviewed articles (Geissdoerfer et al., 2017), mostly used for bibliometric studies due to presenting more standardized and consistent data (Chen et al., 2017a, b). Table 2 shows the criteria used in the search of WoS.

According to the items in Table 2, Fig. 1 presents the sequential procedures of triangulation of the three methods referred to in Table 1.

The data collection process required the definition of the two search strings (search 1 and 2), supported by the previous reading of the literature on eco-cities, without any serial filter, returned 1414 scientific documents, the number of which was reduced to 203 with the application of the serial filters defined in Table 1. On the other hand, the research was carried out on the WoS and the documents taken from the Science Citation Index (SCI), Science Citation 


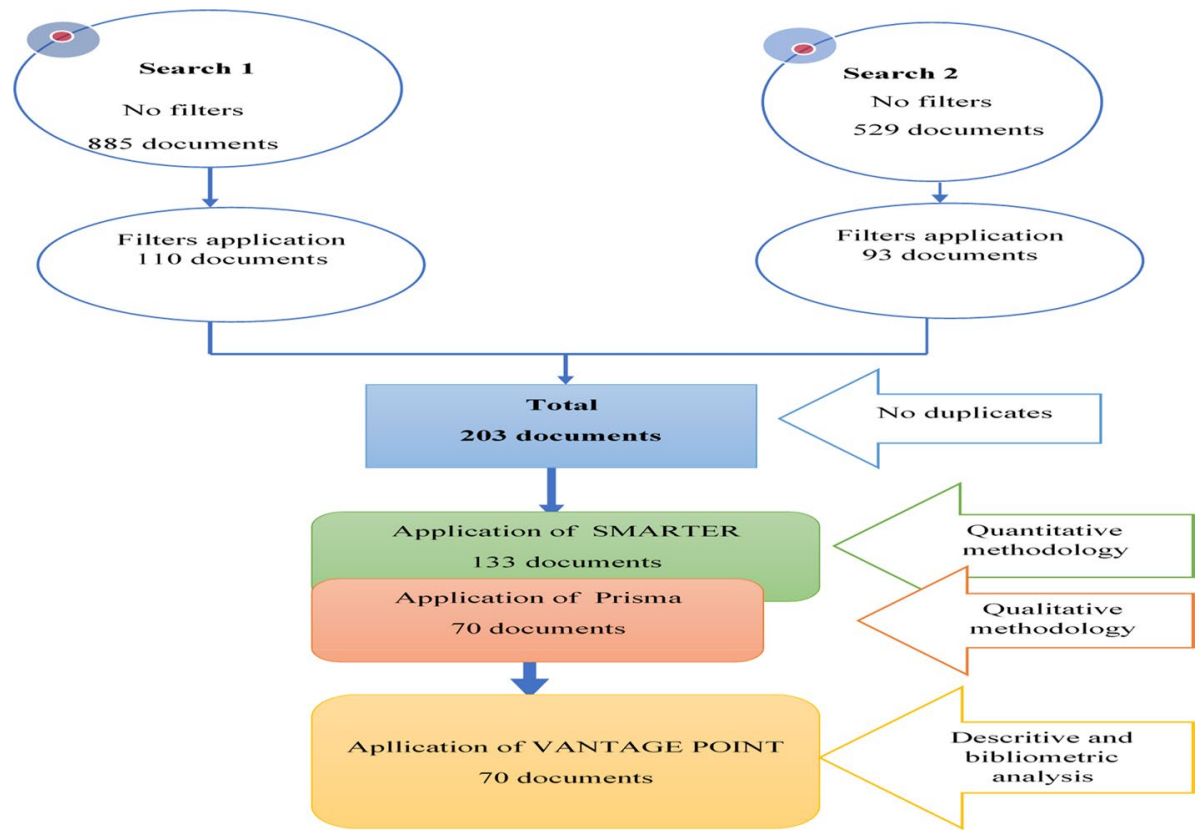

Fig. 1 Methodological procedures

Table 2 Keywords and systematization criteria for the search

\begin{tabular}{|c|c|}
\hline Items & Criteria \\
\hline Keywords & $\begin{array}{l}\text { Search } 1-(" \text { "eco cit*" or "eco-cit*" or "ecological cit*" } \\
\text { or "green cit*" and "sustainability" or "triple bottom") } \\
\text { Search } 2-(" e c o \text { cit*" or "eco-cit*") }\end{array}$ \\
\hline Date of search & 23 March 2020 \\
\hline Period of time & No chronological filter \\
\hline Language & English \\
\hline Type of document & Article or review, Proceedings papers and Book Review \\
\hline Area of search & $\begin{array}{l}\text { Environmental Studies or Business or Business Finance } \\
\text { or Regional Urban Planning or Economics or Man- } \\
\text { agement or Urban Studies }\end{array}$ \\
\hline
\end{tabular}

Index Expanded (SCI-Expanded), Social Science Citation Index (SSCI) and Social Scientific Citation Index (AHCI) compiled by Thomson / Reuters, in ISI's online database, one of the largest repositories and frequently used in this type of research, which includes numerous scientific publications and all bibliographic information about their authors, citations, journals, among others. Based on the 203 documents obtained, it became crucial to proceed to a scientific cut, using the SMARTER method, which led to the definition of decision criteria shown in Fig. 2. Thus, this method reduced the final basis to be analysed in this study, for 133 articles. However, since this is a quantitative methodology, the application of the PRISMA method was crucial to analyse the 133 articles by means of two eligibility criteria (Fig. 4), 


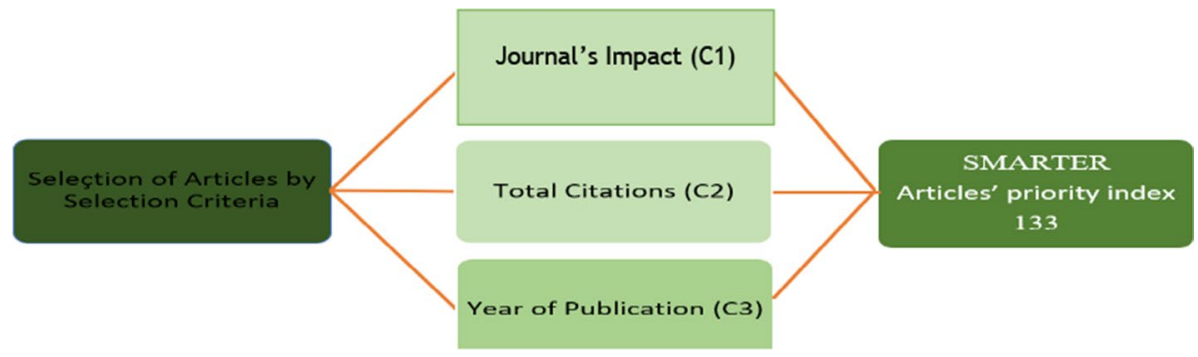

Fig. 2 SMARTER Criterion ( adapted from Keeney \& Raiffa, 1976)

which resulted in the reduction of the final base to 70 documents. Finally, bibliometrics was applied to 70 documents by using VANTAGE POINT for the operationalization of a metaanalysis. These methodological procedures are explained in detail in the following sections.

\subsection{Document selection}

The SMARTER method was applied to the total of 203 documents selected. This adopts different criteria to assess different alternatives for different lines of arguments (Marques \& Franco, 2020) and in this way present a common result (Garza-Reyes, 2015). Figure 2 shows the criteria used for systematization of the 133 articles (see Fig. 1).

With this method, it is essential to define the relative importance of the criteria and respective weights, i.e. exploration of the ordering of criteria (Marques \& Franco, 2020). According to Olson and Dorai (1992), the centroid method attributes different weights, where W1 is the weight of the most important objective, W2 the weight of the second most important objective and $W_{k}$ for the most important $\mathrm{K}$ objective. Consequently, for the $\mathrm{K}$ objectives, we have Eqs. 1, 2 and $\mathrm{K}$, the importance of the respective criteria, with the total sum of weights equal to 1 (Olson \& Dorai, 1992):

$$
w_{1}=(1+1 / 2+1 / 3+\ldots+1 / k) / k
$$

Edwards and Barron (1994) presented the stages to be followed rigorously in this method, as summarized in Table 3.

Table 4 presents the potential alternatives $\left(\boldsymbol{A}_{n}\right)$ for the 203 documents (S4).

The steps defined in S4 led to S5, obtained by creating a spreadsheet with the following Eqs. 1-5 applied to all D203s, as follows:

$$
\begin{array}{lc}
\text { Citescore }-\mathrm{f} x \mathrm{C} 1 & 1.115(\text { Table } 4)-0.1458(\text { Table } 5) \\
\text { Citations }-\mathrm{f} x \mathrm{C} 3 & 0(\text { Table } 4)-0.04(\text { Table } 5) \\
\text { Year }-\mathrm{f} x \mathrm{C} 3 & 1996(\text { Table } 4)-0.04(\text { Table } 5) \\
\Sigma(\mathrm{f} x C 1 \times \mathrm{W} 1)+(\mathrm{f} x C 2 \times \mathrm{W} 2)+(\mathrm{f} x C 3 \times \mathrm{W} 3)=\text { Roc Weights } \\
\sum(0.1458 \times 0.611)+(0.04 \times 0.2778)+(0.04 \times 0.1111)=0.104654 \\
\left(\begin{array}{c}
(T a b l e ~ 5 \text { ande Table } 6)
\end{array}\right.
\end{array}
$$


Table 3 Stages (S)

S1 -Objectives and decision-making: ordering of the alternatives for selection of the state of the art by the decision-maker

S2 - Hierarchy of the attributes defined to value the alternatives

S3 -Alternative articles to be used to replicate the model proposed, through a search of WoS with the keywords and filters indicated in Table 2 (Table 4)

S4 - Articles assessed by the type of attribute (Table 4 ), with $\mathbf{n}=\mathbf{2 0 3}$ potential alternatives $\left(\boldsymbol{A}_{n}\right)$ according to $\mathbf{m}=\mathbf{3}$ criteria $\left(\boldsymbol{C}_{\boldsymbol{m}}\right)$ to be applied to S3

$\mathrm{S} 5$ - Analysis of the values obtained for the criteria defined in $\mathrm{S} 4$

S6 - Assessment according to $\boldsymbol{C}_{\boldsymbol{m}}$ : C1-Citescore and $\mathbf{C 2}$ - Number of citations are functions of maximization, where the higher the value, the greater the utility; C3 - Time, assesses performance in qualitative terms. The weights used are those of the ROC curve (Centroid Order) (Roberts \& Goodwin, 2002) (Table 5)

S7 - Ordering of attributes $\left(\boldsymbol{W}_{3}\right)$ according to the decision-maker (Table 6)

S8 - Use of the ROC weights for $\boldsymbol{W}_{3}$ (Table 6)

S9 - Decision: calculation of all utilities for the attributes $\left(\boldsymbol{W}_{3}\right): U_{j=} \Sigma_{k} \cdot w_{k} \cdot u_{j k}($ Table 6)

An Potencial alternatives, $\mathrm{Cm}$ Criterion, $\mathrm{Wm}$ Roc weights

Table 4 Summary of the assessment matrix

\begin{tabular}{llll}
\hline Documents (D) & $\begin{array}{l}\text { C1 (Citescore } \\
2018)\end{array}$ & $\begin{array}{l}\mathrm{C} 2\left(\mathrm{~N}^{\circ} \text { Cita- }\right. \\
\text { tions) }\end{array}$ & $\begin{array}{l}\text { C3 Time } \\
\text { (Publication } \\
\text { year) }\end{array}$ \\
\hline D1 & 0.944 & 401 & 2006 \\
D2 & 2.124 & 187 & 2005 \\
D3 & 1.371 & 173 & 2006 \\
D4 & 3.853 & 138 & 1997 \\
$\ldots$ & - & - & - \\
D203 & 1.115 & 0 & 1996 \\
\hline
\end{tabular}

Table 5 shows the weights of the ROC curve used to analyse assessment of the criteria (S6), as defined by Roberts and Goodwin (2002).

Finally, Table 6 contains the utilities for each attribute $\left.\left(\boldsymbol{W}_{\mathbf{3}}\right)\right)$.

From the results obtained in the nine stages and through Fig. 3, the cut year can be determined, as graphic representation of the ROC curve shows the cut axis. This means that the ROC curve has the great advantage of allowing a relation to be established between sensitivity and specificity and representing the whole universe of possible events (Azevedo \& Pereira, 2010).

In Fig. 3, the cut is the penultimate point on the ROC curve, i.e. a value of 96.13 for sensitivity and 64.52 for specificity, meaning a cut in the ROC weights from 64.52. In this specific case, the cut of the 133 documents is according to time, which defined a cut of approximately 10 years from the date of publication (Cerón-Palma et al., 2012).

After determining the cut year (2012) PRISMA was applied (Fig. 4) to obtain the final sample of documents for the bibliometric analysis using VANTAGE POINT.

\subsection{Qualitative (descriptive) and quantitative analysis}

The typology of the final 70 documents selected presents the distribution shown in Fig. 5. 
Table 5 Analysis of assessment of the criteria

\begin{tabular}{lll}
\hline Function $(f x)$ & Definition & Weight \\
\hline C1 & Journal's Citescore (2018) & \\
& 4.01 or more & 0.5208 \\
& $2.01-4.00$ & 0.2708 \\
$1.01-2.00$ & 0.1458 \\
& $0-1.00$ & 0.0625 \\
& Number of citations & \\
C2 & 11-20 more & 0.4567 \\
& $4-10$ & 0.2567 \\
& $1-3$ & 0.1567 \\
& 0 & 0.0900 \\
& Time criterion (year of publication) & \\
2014-2020 & 0.0400 \\
& $2004-2008$ & 0.4567 \\
& 2009-2013 & 0.2567 \\
& $1999-2003$ & 0.1567 \\
& $1996-1998$ & 0.0900 \\
& & 0.0400 \\
\hline
\end{tabular}

ROC Curve

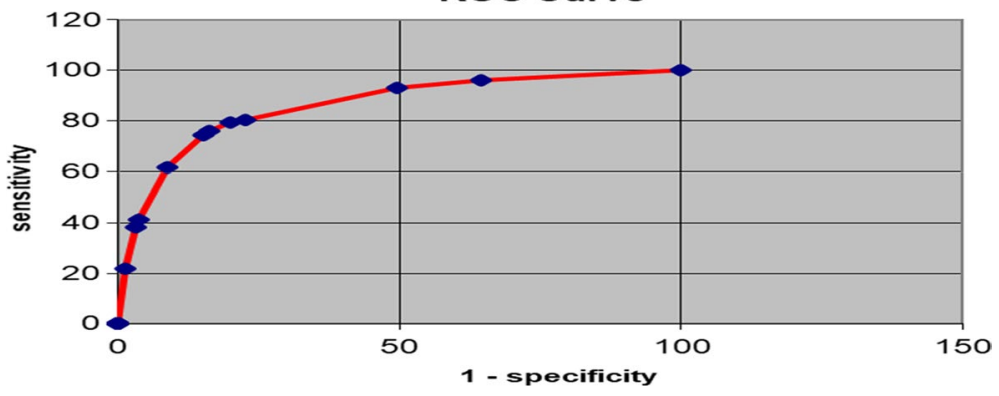

Fig. 3 Roc Curve ( adapted from Zweig \& Campbell, 1993)

Figure 5 clearly shows the prevalence of scientific articles on other typologies of documents and shows the areas of research they deal with, highlighting that most studies are related to searching on the term of "Urban Studies"(e.g. Caprotti et al., 2015; Flynn et al., 2016; Lee, 2015; Lin, 2018; Mehmood, 2016; Mneimneh et al., 2017; Tateishi, 2018; Wu, 2020; Zhuang, 2015). In other words, the fact there is growing concern about increased population density in cities, with environmental and social consequences, has aroused researchers' interest in urban areas, especially those that have already implemented models of eco-cities, as in the case of China. Successful eco cities include Reykjavik-Iceland, Zurich-Switzerland, Bristol—South West England, Portland-Oregon, VancouverCanada, Copenhagen-Denmark and others (Better World Soluctions.eu, 2021; Joss et al., 2013).

The countries with most publications are shown in Fig. 6.

Once more, China stands out with 26 publications about eco-cities, since a great many studies included here are about this country and the first authors originate there. 


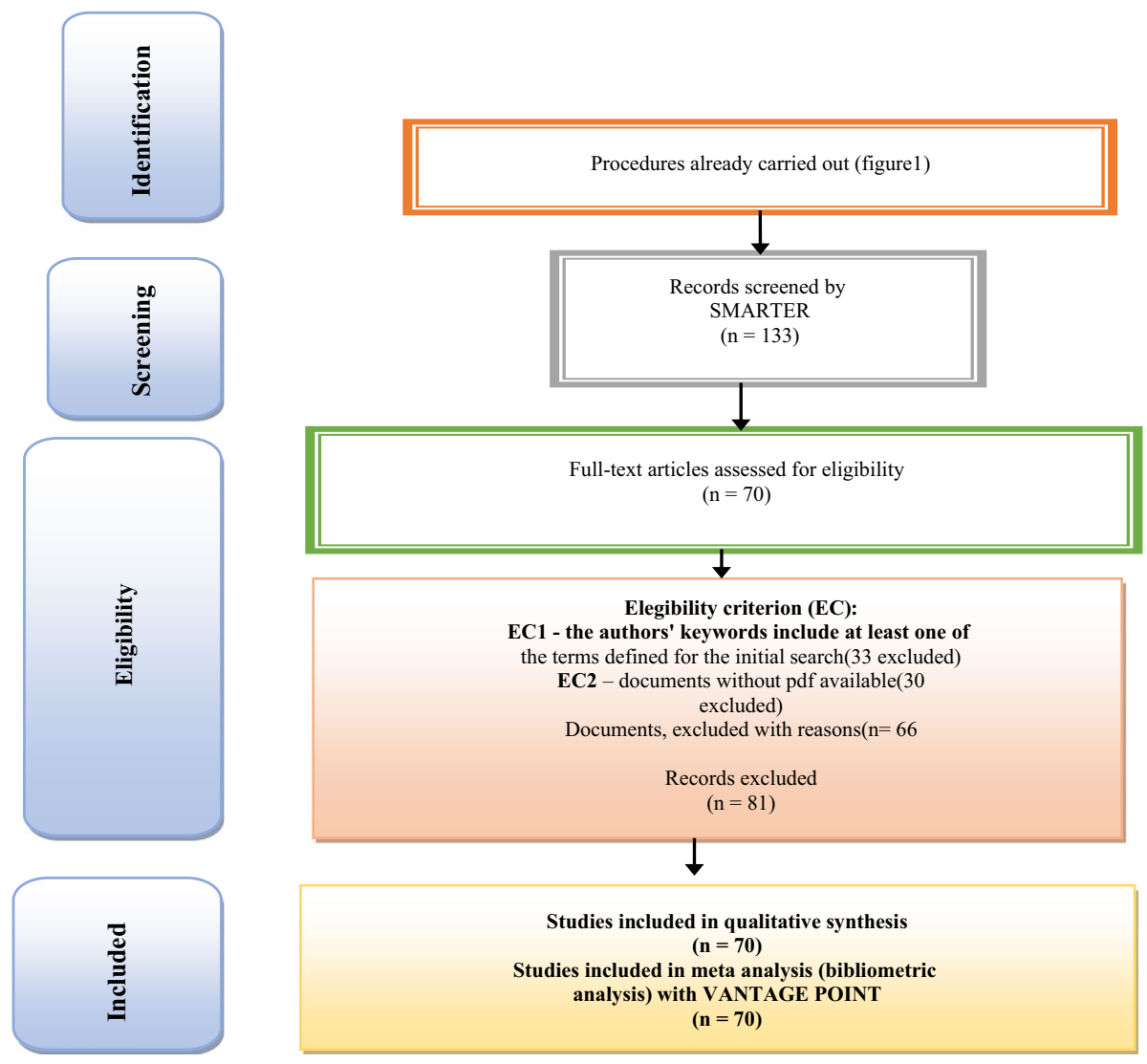

Fig. 4 PRISMA diagram (Liberati et al., 2009)

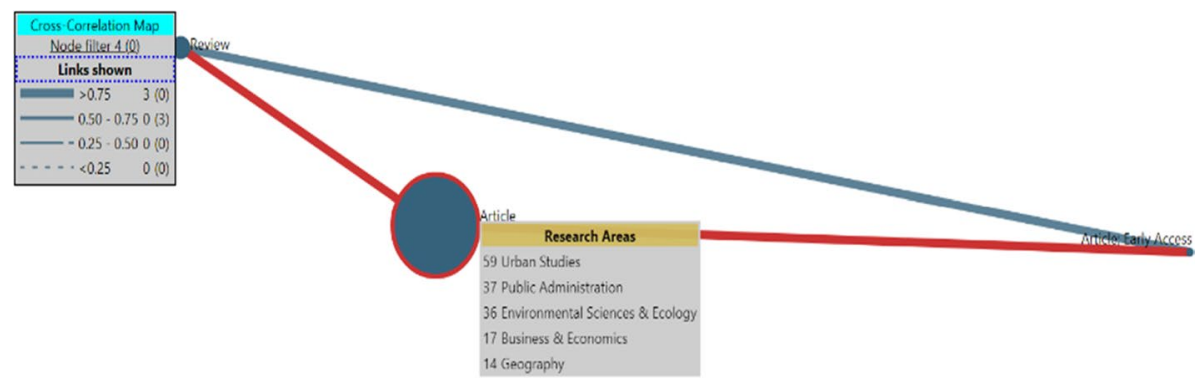

Fig. 5 Cross correlation map of document type crossed with research areas

For example, of the 70 articles analysed here, a great many are empirical studies about China, which is considered one of the pioneers in eco-city projects (e.g. Kang et al., 2019; Li \& Qiu, 2015; Liu et al., 2014; Miao \& Lang, 2015; Rugkhapan \& Murray, 2019; Visser, 2019; Xie et al., 2020; Xu, 2017), Sweden has only six publications in comparison, although Malmo, Sweden, "In the last few years, the city is looking forward to a bright 


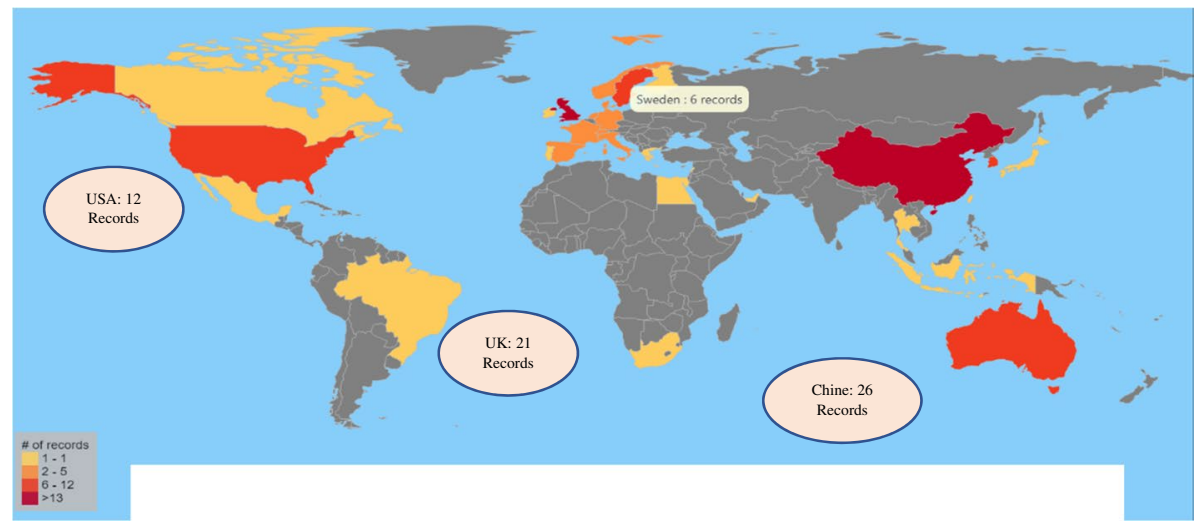

Fig. 6 Publications by country

environmental future. There are many redevelopment projects scheduled that will take care of brownfields and treat soil contamination. The city put a plan in place according to which the whole city will run on renewable energy by 2030 . Malmo is concentrating on reducing greenhouse emission and optimization of transportation facilities, waste management, and proper urban planning." (Better World Soluctions.eu, 2021, p.1).

Also important is the relation existing in studies between countries (Joss \& Molella, 2013; Mullins, 2017; Naguib et al., 2016; Rohracher \& Späth, 2014), as shown in Fig. 7. Here China is the largest circle, due to concentrating on this type of city, albeit with some difficulties (e.g. Dongtan Shanghai, China 2004-Unrealized; Caofeidian Tangshan, China 2007-Unfinished) (Saiu, 2017). This does not mean there are no successful cases-we already have many examples of successful implementation of ecocity principles around the world. (Mersal, 2017, p. 31).

Lexical analysis of the 70 documents also shows the terms occurring most frequently in the articles' contents (Fig. 8).

The word-cloud reveals the emergence of the words "eco-city, China, governance, transitions" in the documents selected on this topic.

The most cited of the total 70 articles are shown in Table 7.

Cross-Correlation Map of Countries/Regions Crossed with Countries/Regic

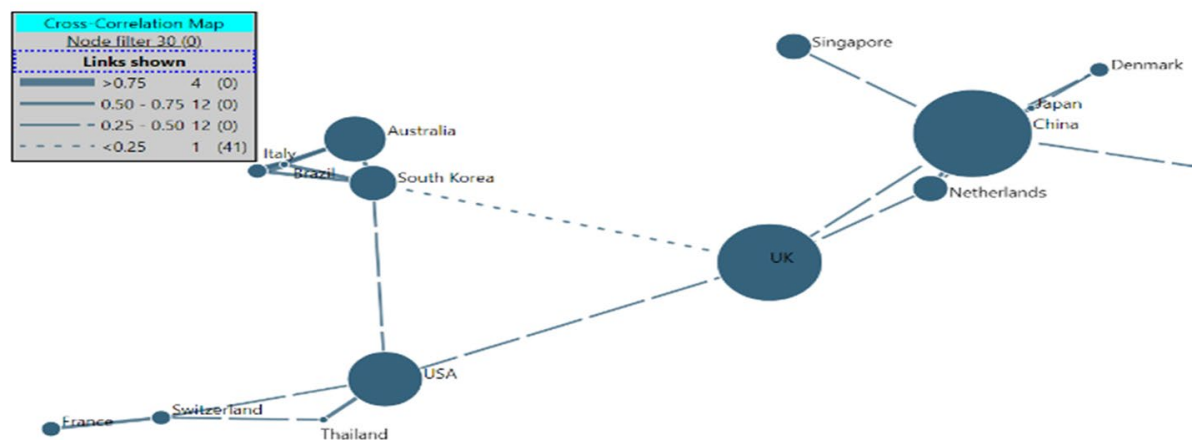

Fig. 7 Cross-correlation between countries and regions 


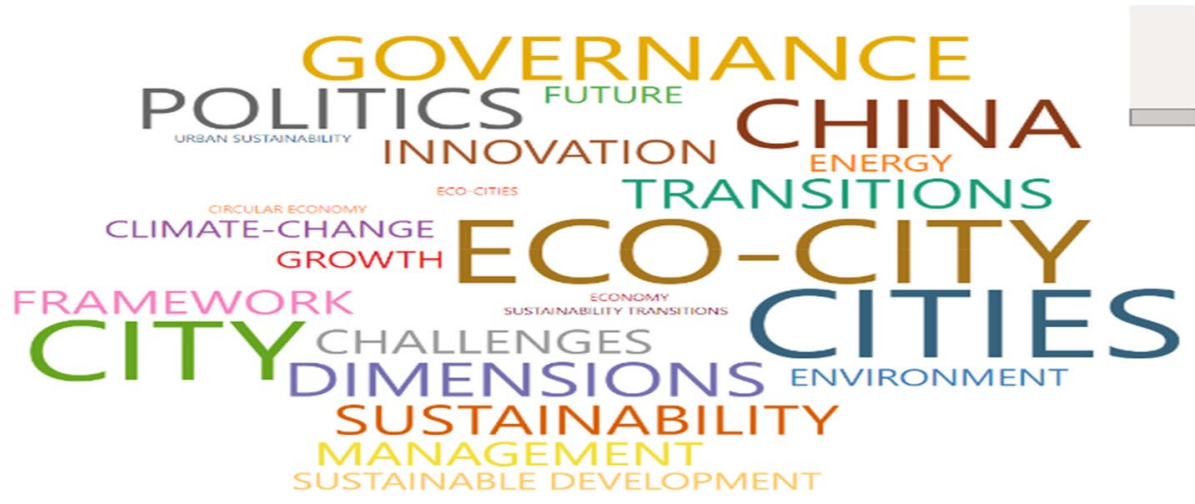

Fig. 8 Word-cloud

Table 6 Order of attributes according to relevance and ROC weights, pre-defined

\begin{tabular}{llll}
\hline Order of attributes & 1 & 2 & 3 \\
& Journals (C1) & Citations (C2) & Time (C3) \\
\hline Weights & W1 (attribute 1) & W2 (attribute 2) & W3 (attribute 3) \\
& 0.6111 & 0.2778 & 0.1111 \\
\hline
\end{tabular}

The above table provides various interpretations. The first is that the most cited article (135) is about eco-cities in Africa, which intends to highlight the fantasy of implementing this type of city in that region, but without presenting any scientific bibliographic references (Watson, 2014). The second is that the JOURNAL OF URBAN TECHNOLOGY is the journal with most articles (5) in this list with a citescore of 2.25 (Quartile 1), while CITIES with a citescore of 3.853 only presents 2 articles (Anthopoulos, 2017; Caprotti, 2014), although the one by Anthopoulos, (2017) is in the second position in the Top 10 with 95 citations. Finally, the year 2014 includes four articles, with the most recent article being from 2017 (Anthopoulos, 2017).

No less important is the number of publications per year (Fig. 9), with 2017 having most publications, followed by 2014. It stands out that 2014 has five articles in the Top 10 .

The prevalence of 2017 with most publications shows it is important to study how strategies are used in eco-city projects, to understand the transition of other cities to this typology, because, as explained by the European Union, it is urgent to achieve global, long-term sustainability (UE, 2021).

Bibliometric analyses generally show author clusters for the articles on their databases. However, this study presents the cross-correlations between authors and keywords, as shown in Fig. 10. There are two main clusters, where the size of the node reflects the volume of associated registers and the lines the measures of similarity.

Cluster 1 includes the words "sustainable city, eco-city" and Cluster 2 the words "eco-city, China, sustainable urban development and eco-cycle model". There is also a correlation between all the authors shown around the two largest nodes, for example, Caprotti (2014) in Cluster 1, whose keywords were used by the authors in the smaller nodes on the right; Caprotti (2014) analysed Tianjin Eco-City, China, as the starting point for discussion on eco-city projects in the light of their definition, social resilience 


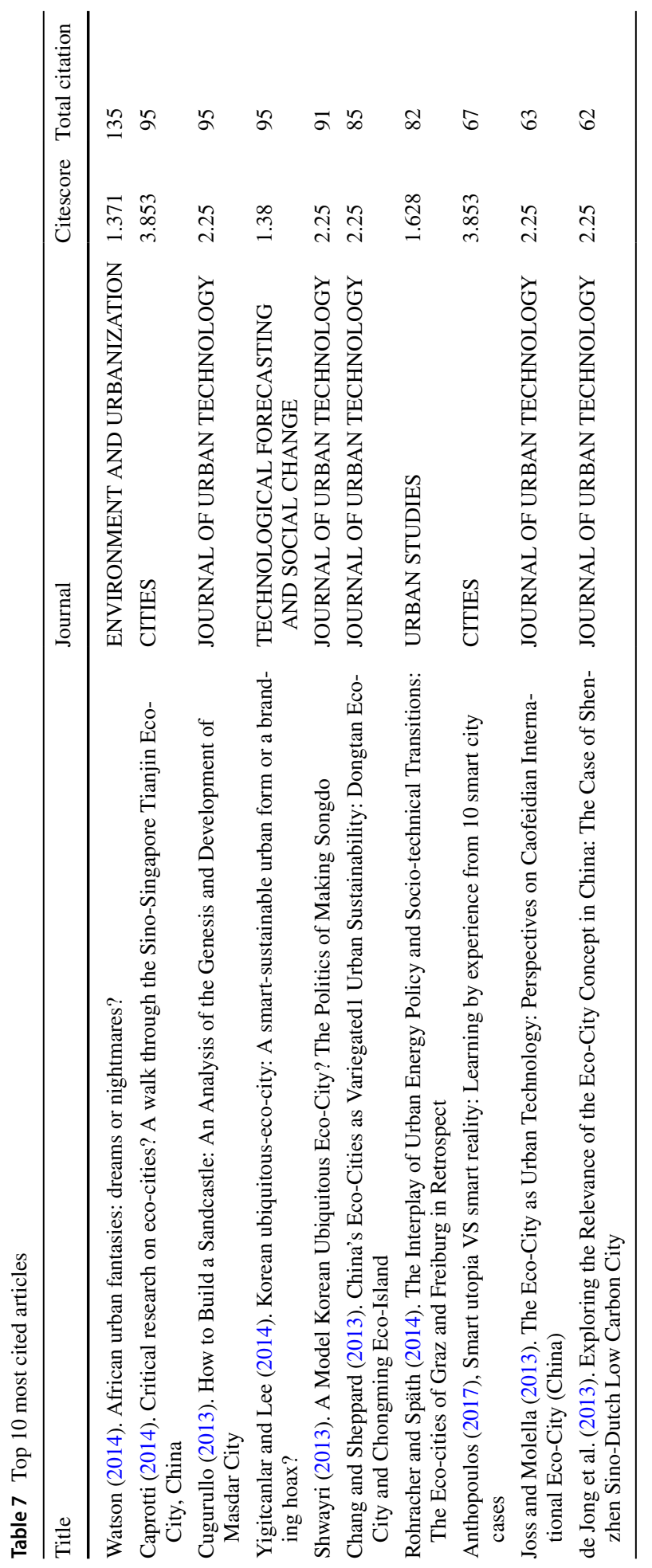




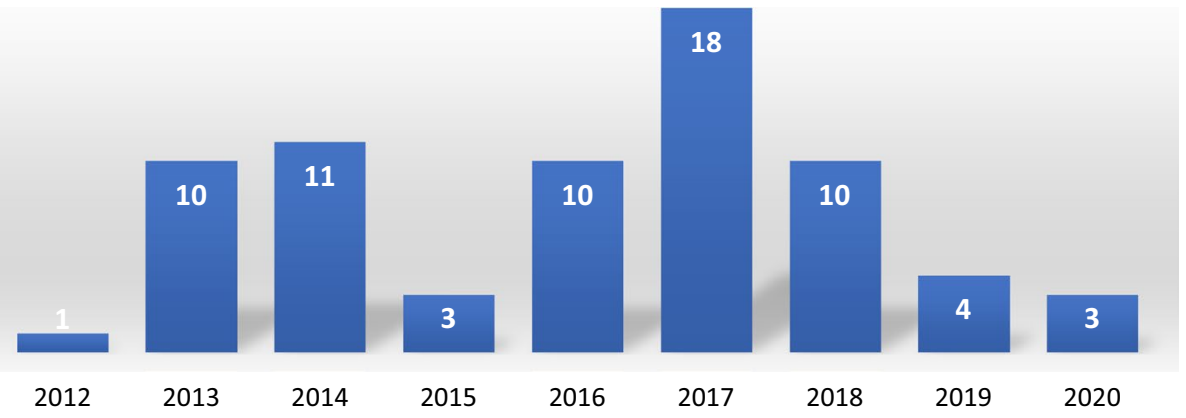

Fig. 9 Publications by year

Cross-Correlation Map of Authors (Clustered) Crossed with Keywords (author's)

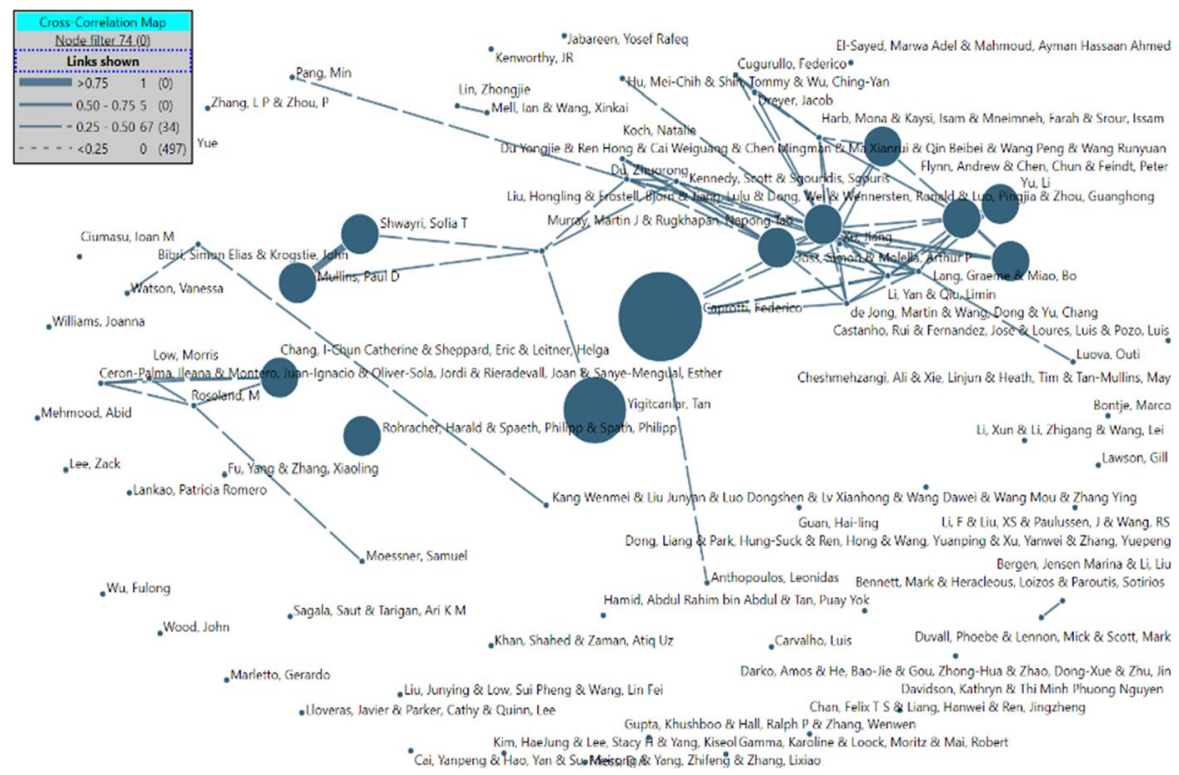

Fig. 10 Cross correlation map; authors vs keywords

and urban population growth, aiming to raise new questions in future research on the topic. Li and Qiu (2015) also made a comparative study between Suzhou (China) and Kitakyushu (Japan), as examples of reference on eco-cities, to analyse the structural development of this type of city by the Chinese government and their quality. These authors concluded that the Chinese city showed a notable evolution in its green spaces and environmental infrastructure, despite persistent gaps in indicators to measure environmental quality. Miao and Lang (2015) considered two ambitious eco-city projects launched in China in the last 15 years-the "Dongtan eco-city" project in Shanghai (currently halted) and the Sino-Singaporean Tianjin Eco-City (in progress) in Tianjin, aiming to understand the status of each of them. The Dongtan project failed due to the 
lack of more government support, financial funding and international knowledge inputs. Finally, Liu et al. (2014) argued that the complexity surrounding sustainability and future uncertainties suggests the construction of more robust, resilient, as well as sustainable, cities to address climate change and the shortage of resources. Standing out in Cluster 2 is Yigitcanlar (2015), who made a critical review of the smart city model and the application of intelligent urban technology, analysing particularly emerging practices of ubiquitous eco-cities as examples of smart city initiatives, concluding that city planning should consider the implications of those technologies in achieving sustainable environments in the future. Included in this cluster is the ROC cut-off article (CerónPalma et al., 2012) which examined the obstacles and opportunities related to implementing Rooftop Eco.Greenhouses in Mediterranean cities in Europe, these being ecological greenhouses that improve the sustainability of buildings in cities. The authors concluded that the sustainable urban model for the future should facilitate the exchange between cities, for example.

With this being a topic of great interest to academics, town planners, politicians and other entities, it is concluded that the construction of an eco-city is undoubtedly an extremely complex process. In other words, the ideal eco-city would be built from scratch, which in most cases is not possible, given the case of China with its unfinished projects, or by implementing eco-spaces within existing cities. Therefore, presenting a theoretical framework for these cities means including questions of various typologies of existing cities and regrouping them according to the definition of the eco-city. In these circumstances, the model presented here (Fig. 11) is supported by the keywords of Clusters 1 and 2 and

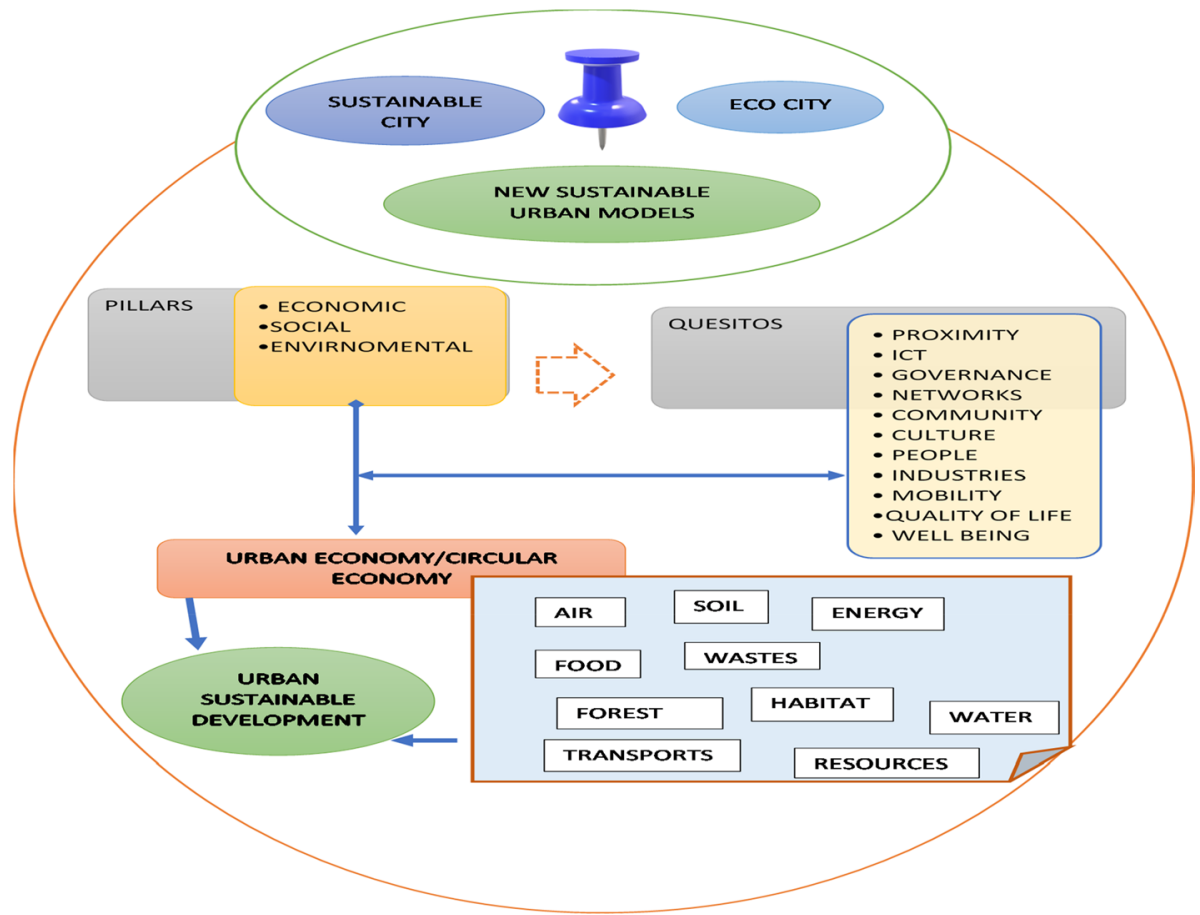

Fig. 11 Theoretical framework of the future of cities 
the respective articles at their origin. It is paramount that eco-cities should not neglect any urban actor, and specifically residents, who in the midst of the current COVID 19 pandemic look increasingly for a sustainable future, environmental, social and economic safety, and a high quality of life.

\section{Conclusion and contributions}

The topic studied here is complex and controversial, as it involves numerous economic, social and environmental questions. These questions are directed to the building of cities that can stimulate global sustainability. In this context, research related to eco-cities has not included any article mapping only the term eco-city, as studies have interlinked this with other topics, such as smart cities, technological infrastructure, maximizing energy efficiency and reducing greenhouse gas emissions among many other issues. Therefore, the bibliometric mapping carried out revealed that studies eligible according to various criteria defined were empirical, with comparative studies and focusing mainly on China. The predominance of this country is justified by the fact that in May 2003, the Chinese state established a plan to build ecological urban areas (Li \& Qiu, 2015). However, the unfinished projects aroused even greater interest in understanding why.

The mapping and bibliometrics presented here suggest that cities have to be approached holistically in all their dimensions, as argued by Vakula et al. (2018). This means that the urban buzz of cities must involve all the ergonomics of their ecosystems to achieve the desired sustainability and reduce the ecological footprint, although this is a high ambition (Xie et al., 2020). It should be noted, the rapid urbanization that has been seen in the global urban area has triggered environmental and socio-economic challenges, which include climate change and pollution, among others, which can be understood as an opportunity for the transition to more ecological cities, supported by the models of success of eco cities (e.g. Madrid, Singapore, Zurich, Bristol and Vancouver) and, at the same time, economically sustainable, assuming cities as the driving vehicles for this potential lasting change.

The bibliometric methods used, particularly SMARTER, PRISMA and VANTAGE POINT, are original in management studies and studies on urban spaces, which is an original contribution of this research. This study showed the importance of continuing to study sustainable city models already developed by the scientific community and proceed with empirical studies on them, to conclude about their weaknesses and strengths and, thus, promote future improvements. Farther the importance of the transition to a model of a circular economy, as highlighted by the European Union, the theoretical framework proposed here aims to show that cities, of any typology, should promote their economic, social and environmental development without neglecting community life, history, local values and culture, proximity, mobility, good governance practices, information and communication technology (ICT), the network functioning of hard and soft infrastructure, and people, to be able to provide their residents with quality of life and well-being. Furthermore, the pillars and issues of cities should be directed towards a circular urban economy, in order to reduce the ecological footprint by diminishing the use of non-renewable resources, maximizing energy efficiency and reducing greenhouse gas emissions, among other measures. It is important to mention that these considerations to the presented framework do not aim to define the direction of the future development of cities, nor to recall the obligations of local authorities, but rather a useful guide for all economic and non-economic actors crucial for the sustainable development of ecosystems in cities in a near future. 
Another contribution to theory lies in adopting a mixed methodological approach where the research techniques used-qualitative PRISMA method and the quantitative SMARTER and VANTAGE POINT methods-are complementary rather than mutually exclusive (Minayo \& Sanches, 1993; Patton, 1991, 2002). Therefore, this approach overcame the weaknesses of the quantitative and qualitative methods, as this triangulation allowed the external and internal validity of the research presented here.

Concerning implications for practice, the articles reviewed show the importance of continuing with research to identify cases of success and failure, to provide lessons for future projects. In addition, sustainability and concern about climate change, among many other aspects, should always be present in those projects. This is even more urgent, given the current COVID 19 pandemic and all its tangible and intangible consequences, and the increased ecological footprint witnessed. In addition, the empirical contributions of the studies presented here provide practical implications for public policy and local authorities. These types of studies are essential for local governments and political decision-makers to be able to take corrective measures in the various axes of their urban economic growth strategies at the macro-, micro- and meso-levels to achieve the intelligent, inclusive and sustainable growth aimed for by the European Union.

Like any study, this one is not without limitations. The first concerns only using WoS, despite this being recognized internationally as the most widely used. The second has to do with the search terms used, as many others could have been employed. Finally, the bibliometric methods adopted do not preclude others.

These limitations suggest various indications for the future. The first would be to use the WoS and SCOPUS databases to replicate this study. The second would be to add search terms, such as infrastructure, technology, intelligence, greenhouse gases, waste, pollution and energy efficiency. As this is a fertile field of research, also suggested is study of all smart cities of reference, to determine if they can be framed in the ecocity concept, and research relating this concept to the transition to the circular economy model. It would also be interesting to study the eco-city model implemented in Korea. Finally, using other bibliometric software would provide numerous paths for the future, given the proliferation of this, as well as using SMARTER through SPSS software.

Finally, this study showed that the trend topics for future research are fertile, due to the wide-ranging nature of the eco-city concept. Continued study of Chinese eco-cities is certainly pertinent for better understanding of their strengths and weaknesses, and also as in that country it is the government's will to construct eco-cities, studying why in these cities with excellent systems to monitor epidemics (e.g. Singapore), COVID 19 did not occur to a lesser extent. Another topic would be to study how eco-cities worldwide reach a balance between the rural city and the urban city, as mentioned by Register (1987, 2006). The relation between eco-cities and sustainability is also seen to be a trend topic in need of more research, in order to understand how a sustainable city can be transformed into an eco-city, as it would be utopian to believe that eco-cities of the future could be built from scratch.

Acknowledgements The authors are grateful to the anonymous referees of the journal for their extremely useful suggestions to improve the quality of the paper. The authors gratefully acknowledge financial support from National Funds of the FCT-Portuguese Foundation for Science and Technology within the project «UIDB/04007/2020». 


\section{References}

Alberti, M. (2008). Advances in urban ecology: Integrating humans and ecological processes in urban ecosystems (No. 574.5268 A4). NewYork: Springer.

Anthopoulos, L. (2017). Smart utopia VS smart reality: Learning by experience from 10 smart city cases. Cities, 63, 128-148. https://doi.org/10.1016/j.cities.2016.10.005

Azevedo, L., \& Pereira, A. (2010). Avaliação Crítica e Implementação Prática de Estudos Sobre a Validade de Testes Diagnósticos - Parte I. Nascer e Crescer, 19(4), 265-277.

Barfod, M. B., Kaplan, S., Frenzel, I. (2016) COPE -SMARTER-A decision support system for analysing the challenges, opportunities and policy measures: A case study of electric commercial vehicles market diffusion un Denmark. Research in Transportation Economics, 55, 3-11. Retrieved from http://orbit.dtu.dk/ws/files/127448998/COPE_SMARTER_A_decision_support_system_for_ analysing_the_challenges_opportunities_and_policy_initiatives.pdf

Better World Soluctions.eu. (n.d.). Top 10 -Eco-cities. Retrieved August 23, 2021, from https://www. betterworldsolutions.eu/top-10-eco-cities/

Briner, R. B., \& Denyer, D. (2012). Systematic review and evidence synthesis as a practice and scholarship tool. In The Oxford Handbook of Evidence-Based Management pp. 112-129.

Bryman, A. (2012). Social research methods (4th ed.). Oxford University Press.

Bulkeley, H. (2006). Urban sustainability : learning from best practice ? Environment and Planning A, 38(1), 1029-1045. https://doi.org/10.1068/a37300

Caprotti, F. (2014). Critical research on eco-cities? A walk through the Sino-Singapore Tianjin Eco-City, China. Cities, 36, 10-17. https://doi.org/10.1016/j.cities.2013.08.005

Caprotti, F., \& Romanowicz, J. (2013). Thermal eco-cities: Green building and urban thermal metabolism. International Journal of Urban and Regional Research, 37(6), 1949-1967. https://doi.org/ 10.1111/1468-2427.12049

Caprotti, F., Springer, C., \& Harmer, N. (2015). "Eco" for whom? Envisioning eco-urbanism in the Sino-Singapore Tianjin Eco-city, China. International Journal of Urban and Regional Research, 39(3), 495-517. https://doi.org/10.1111/1468-2427.12233

Cerón-Palma, I., Sanyé-Mengual, E., Oliver-Solà, J., Montero, J. I., \& Rieradevall, J. (2012). Barriers and opportunities regarding the implementation of rooftop eco.greenhouses (RTEG) in Mediterranean cities of Europe. Journal of Urban Technology, 19(4), 87-103. https://doi.org/10.1080/10630 732.2012 .717685

Cetin, M. (2015a). Evaluation of the sustainable tourism potential of a protected area for landscape planning: A case study of the ancient city of Pompeipolis in Kastamonu. International Journal of Sustainable Development and World Ecology, 22(6), 490-495. https://doi.org/10.1080/13504509. 2015.1081651

Cetin, M. (2015b). Using GIS analysis to assess urban green space in terms of accessibility: Case study in Kutahya. International Journal of Sustainable Development and World Ecology, 22(5), 420424. https://doi.org/10.1080/13504509.2015.1061066

Cetin, M. (2016). Sustainability of urban coastal area management: A case study on Cide. Journal of Sustainable Forestry, 35(7), 527-541. https://doi.org/10.1080/10549811.2016.1228072

Chang, I. C. C., \& Sheppard, E. (2013). China's eco-cities as variegated1 Urban sustainability: dongtan eco-city and chongming eco-Island. Journal of Urban Technology, 20(2), 57-75. https://doi.org/ 10.1080/10630732.2012.735104

Chang, Y. W., Huang, M. H., \& Lin, C. W. (2015). Evolution of research subjects in library and information science based on keyword, bibliographical coupling, and co-citation analyses. Scientometrics, 105(3), 2071-2087. https://doi.org/10.1007/s11192-015-1762-8

Chen, H., Jiang, W., Yang, Y., Yang, Y., \& Man, X. (2017a). State of the art on food waste research: a bibliometrics study from 1997 to 2014. Journal of Cleaner Production, 140, 840-846. https://doi.org/10. 1016/j.jclepro.2015.11.085.

Chen, W., Liu, W., Geng, Y., Brown, M. T., Gao, C., \& Wu, R. (2017b). Recent progress on emergy research: A bibliometric analysis. Renewable and Sustainable Energy Reviews, 73(January), 10511060. https://doi.org/10.1016/j.rser.2017.02.041.

Choulak, M., Marage, D., Gisbert, M., Paris, M., \& Meinard, Y. (2019). A meta-decision-analysis approach to structure operational and legitimate environmental policies - With an application to wetland prioritization. Science of the Total Environment, 655, 384-394. https://doi.org/10.1016/j. scitotenv.2018.11.202

Cobo, M. J., López-Herrera, A. G., Herrera-Viedma, E., \& Herrera, F. (2011). An approach for detecting, quantifying, and visualizing the evolution of a research field: A practical application to the 
Fuzzy Sets Theory field. Journal of Informetrics, 5(1), 146-166. https://doi.org/10.1016/j.joi. 2010.10.002

Connor, D. O., \& Voos, H. (1981). Empirical laws, theory construction and bibliometrics. Library Trends, (summer), https://doi.org/10.1080/19338244.2010.483622

Cugurullo, F. (2013). How to build a sandcastle: an analysis of the genesis and development of Masdar City. Journal of Urban Technology, 20(2), 23-37. https://doi.org/10.1080/10630732.2012.735105

Dolan, J. G. (2010). Multi-criteria clinical decision support. The Patient: Patient-Centered Outcomes Research, 3(4), 229-248.

de Jong, M., Wang, D., \& Yu, C. (2013). Exploring the relevance of the eco-city concept in China: The case of Shenzhen sino-dutch low Carbon City. Journal of Urban Technology, 20(1), 95-113. https://doi. org/10.1080/10630732.2012.756202

de Minayo, M. C. S., \& Sanches, O. (1993). Quantitativo-qualitativo: oposição ou complementaridade? Cadernos De Saúde Pública, 9(3), 237-248. https://doi.org/10.1590/S0102-311X1993000300002

Donato, H., \& Donato, M. (2019). Stages for undertaking a systematic review. Acta Medica Portuguesa, 32(3), 227-235.

Edwards, W., \& Barron, F. H. (1994). Smarts and smarter: Improved simple methods for multiattribute utility measurement. Organizational Behavior and Human Decision Processes, 60, 306-325. https://doi.org/10.1006/obhd.1994.1087

EEE. (2017). Urban environment, European Environment Agency. Retrieved from https://www.eea. europa.eu/pt/themes/urban/intro

Evidence-based, M. P., Healthcare, P., \& Dolan, J. G. (2010). Multi-Criteria Clinical Decision Support. 3(4), 229-248.

Flynn, A., Yu, L., Feindt, P., \& Chen, C. (2016). Eco-cities, governance and sustainable lifestyles: The case of the Sino-Singapore Tianjin Eco-City. Habitat International, 53, 78-86. https://doi.org/10. 1016/j.habitatint.2015.11.004

Garfield, E. (1979). Is citation analysis a legitimate evaluation tool? Scientometrics, 1(4), 359-375. https://doi.org/10.1007/BF02019306

Garza-Reyes, J. A. (2015). Green lean and the need for Six Sigma. International Journal of Lean Six Sigma, 6(3), 226-248. https://doi.org/10.1108/IJLSS-04-2014-0010

Geaney, F., Scutaru, C., Kelly, C., Glynn, R. W., \& Perry, I. J. (2015). Type 2 diabetes research yield, 1951-2012: Bibliometrics analysis and density-equalizing mapping. PLoS ONE, 1O(7), 1-14. https://doi.org/10.1371/journal.pone.0133009

Geissdoerfer, M., Savaget, P., Bocken, N. M. P., \& Hultink, E. J. (2017). The Circular Economy - A new sustainability paradigm? Journal of Cleaner Production, 143, 757-768. https://doi.org/10.1016/j. jclepro.2016.12.048.

Grácio, C. M. C. (2016). Acoplamento bibliográfico e análise de cocitação : Revisão teórico-conceitual. Encontros Bibli, 21(47), 82-99. https://doi.org/10.5007/1518-2924.2016v21n47p82

Hadengue, M., de Marcellis-Warin, N., \& Warin, T. (2017). Reverse innovation : A systematic literature review. International Journal of Emerging Markets, 12(2), 142-182. https://doi.org/10.1108/ IJoEM-12-2015-0272

Hart, S. (2007). Zero carbon cities. Architectural Record, 3, 162-164.

Howard, W., \& Katherine, M. (1998). Visualizing a discipline: An author co-citation analysis of information science, 1972-1995. Journal of the American Society for Information Science, 49(4), $327-355$.

Joss, S., Tomozeiu, D., \& Cowley, R. (2011). Eco-Cities: A Global Survey 2011. In International EcoCities Initiative. Retrieved from www.westminster.ac.uk/ecocities

Joss, S., Cowley, R., \& Tomozeiu, D. (2013). Towards the "ubiquitous eco-city": An analysis of the internationalisation of eco-city policy and practice. Urban Research and Practice, 6(1), 54-74. https://doi.org/10.1080/17535069.2012.762216

Joss, S., \& Molella, A. P. (2013). The eco-city as urban technology: Perspectives on Caofeidian international eco-city (China). Journal of Urban Technology, 20(2), 115-137. https://doi.org/10.1080/ 10630732.2012.735411

Kang, W., Wang, M., Liu, J., Lv, X., Zhang, Y., Luo, D., \& Wang, D. (2019). Building sustainable cities in China: Experience, challenges, and prospects. Chinese Journal of Urban and Environmental Studies, 07(01), 1940002. https://doi.org/10.1142/s2345748119400025

Keeney, R., \& Raiffa, H. (1976). Decisions with multiple consequences: preferences and value tradeoffs. Wiley.

Keeney, R. L., \& Raiffa, H. (1993). Decisions with multiple objectives: preferences and value tradeoffs. Cambridge University Press.

Krippendorff, K. (2012). Content Analysis: an Introduction to its Methodology. Sage Publications. 
Lee, Z. (2015). Eco-cities as an assemblage of worlding practices. International Journal of Built Environment and Sustainability, 2(3), 183-191.

Li, Y., \& Qiu, L. (2015). A comparative study on the quality of China's eco-city: Suzhou vs Kitakyushu. Habitat International, 50, 57-64. https://doi.org/10.1016/j.habitatint.2015.08.005

Liberati, A., Altman, D. G., Tetzlaff, J., Mulrow, C., Gøtzsche, P. C., Ioannidis, J. P. A., \& Moher, D. (2009). The PRISMA statement for reporting systematic reviews and meta-analyses of studies that evaluate health care interventions: explanation and elaboration. Journal of Clinical Epidemiology. https://doi.org/10.1016/j.jclinepi.2009.06.006

Lin, Z. (2018). Ecological urbanism in East Asia: A comparative assessment of two eco-cities in Japan and China. Landscape and Urban Planning, 179(July), 90-102. https://doi.org/10.1016/j.landu rbplan.2018.07.008

Liu, H., Zhou, G., Wennersten, R., \& Frostell, B. (2014). Analysis of sustainable urban development approaches in China. Habitat International, 41, 24-32. https://doi.org/10.1016/j.habitatint.2013. 06.005

Marques, I. C. P., \& Franco, M. (2020). Cooperation networks in the area of health: Systematic literature review. Scientometrics, 122(3), 1727-1750. https://doi.org/10.1007/s11192-019-03341-3

Mehmood, A. (2016). Of resilient places: Planning for urban resilience. European Planning Studies, 24(2), 407-419. https://doi.org/10.1080/09654313.2015.1082980

Mentzer, J. T., \& Kahn, K. B. (1995). A framework of logistic reserarch. Journal of Business Logistics, $16(1), 231-250$.

Mersal, A. (2017). Eco City Challenge and Opportunities in Transferring a City in to Green City. Procedia Environmental Sciences, 37, 22-33. https://doi.org/10.1016/j.proenv.2017.03.010

Miao, B., \& Lang, G. (2015). A Tale of two Eco-Cities: Experimentation under hierarchy in Shanghai and Tianjin. Urban Policy and Research, 33(2), 247-263. https://doi.org/10.1080/08111146.2014. 967390

Mneimneh, F., Srour, I., Kaysi, I., \& Harb, M. (2017). Eco-City projects: Incorporating sustainability requirements during pre-project planning. Journal of Urban Technology, 24(1), 47-74. https://doi. org/10.1080/10630732.2016.1175828

Moffatt, S., Suzuki, H., \& Iizuka, R. (2012). Eco ${ }^{2}$ cities guide. In Washington DC: The World Bank. Retrieved from http://siteresources.worldbank.org/INTURBANDEVELOPMENT/Resources/ 336387-1270074782769/Eco2_Cities_Guide-web.pdf

Morel, C. M., Serruya, S. J., Penna, G. O., \& Guimarães, R. (2009). Co-authorship network analysis: a powerful tool for strategic planning of research, development and capacity building programs on neglected diseases. PLoS Neglected Tropical Diseases. https://doi.org/10.1371/journal.pntd.00005 01

Mullins, P. D. (2017). The ubiquitous-eco-city of Songdo: An urban systems perspective on South Korea's Green city approach. Urban Planning, 2(2), 4-12.

Naguib, D., Afifi, M., \& Wahba, S. (2016). Towards sustainability in Eco-cities; TDR and possibilities of application on Urban Areas. Procedia Environmental Sciences, 34, 94-103. https://doi.org/10. 1016/j.proenv.2016.04.010

Olson, D. L., \& Dorai, V. K. (1992). Implementation of the centroid method of Solymosi and Dombi. European Journal of Operational Research, 60(1), 117-129. https://doi.org/10.1016/03772217(92)90339-B

Pasadeos, Y., Phelps, J., \& Kim, B. H. (1998). Disciplinary impact of advertising scholars: Temporal comparisons of influential authors, works and research networks. Journal of Advertising, 27(4), 53-70. https://doi.org/10.1080/00913367.1998.10673569

Patton, M. J. (1991). Qualitative research on college students: Philosophical and methodological comparisons with the quantitative approach. Journal of College Student Development., 32, 389-396.

Patton, M. Q. (2002). Two decades of developments in qualitative inquiry: A personal experiential perspective. Qualitative Social Work, 1(3), 261-283. https://doi.org/10.1177/1473325002001003636

Porter, A. L., \& Cunningham, S. W. (2004). Ning: Exploiting new technologies for competitive advantage. Wiley.

Porter, A. L., \& Youtie, J. (2009). How interdisciplinary is nanotechnology? Journal of Nanoparticle Research, 11(5), 1023-1041. https://doi.org/10.1007/s11051-009-9607-0

Powell, W. W., Koput, K. W., \& Smith-Doerr, L. (1996). Interorganizational collaboration and the locus of innovation: Networks of learning in biotechnology. Administrative Science Quarterly, 41(1), 116. https://doi.org/10.2307/2393988

Pradhan, P. (2016). Science mapping and visualization tools used in bibliometric \& scientometric studies: An overview. 23(4). 
Prasad, S., \& Tata, J. (2005). Publication patterns concerning the role of teams/groups in the information systems literature from 1990 to 1999. Information and Management, 42(8), 1137-1148. https:// doi.org/10.1016/j.im.2005.01.003

Quinlan, K. M., Kane, M., \& Trochim, W. M. K. (2008). Evaluation of large research initiatives: Outcomes, challenges, and methodological considerations. New Directions for Evaluation, 2008(118), 61-72. https://doi.org/10.1002/ev.261

Register, R. (1987). Ecocity Berkeley: building cities for a healthy future. North Atlantic Books.

Register, R. (2006). Ecocities: Rebuilding cities in balance with nature. New Society Publishers.

Roberts, R., \& Goodwin, P. (2002). Weight approximations in multi-attribute decision models. Journal of Multi-Criteria Decision Analysis, 11(6), 291-303. https://doi.org/10.1002/mcda.320

Rohracher, H., \& Späth, P. (2014). The interplay of urban energy policy and socio-technical transitions: The eco-cities of graz and freiburg in retrospect. Urban Studies, 51(7), 1415-1431. https://doi.org/ 10.1177/0042098013500360

Rowley, J., \& Slack, F. (2004). Conducting a literature review. Management Research News, 27(6), 31-39. https://doi.org/10.1108/01409170410784185

Rugkhapan, N. T., \& Murray, M. J. (2019). Songdo IBD (International Business District): Experimental prototype for the city of tomorrow? International Planning Studies, 24(3-4), 272-292. https://doi.org/ 10.1080/13563475.2019.1650725

Rutten-Van Mölken, M., Leijten, F., Hoedemakers, M., Tsiachristas, A., Verbeek, N., Karimi, M., \& Baltaxe, E. (2018). Strengthening the evidence-base of integrated care for people with multi-morbidity in Europe using Multi-Criteria Decision Analysis (MCDA). BMC Health Services Research, 18(1), 1-18. https://doi.org/10.1186/s12913-018-3367-4

Saiu, V. (2017). The three pitfalls of sustainable city: A conceptual framework for evaluating the theorypractice gap. Sustainability (switzerland). https://doi.org/10.3390/su9122311

Serapioni, M. (2000). Métodos qualitativos e quantitativos na pesquisa social em saúde: Algumas estratégias para a integração. Ciência \& Saúde Coletiva, 5(1), 187-192. https://doi.org/10.1590/S141381232000000100016

Seuring, S., \& Müller, M. (2008). From a literature review to a conceptual framework for sustainable supply chain management. Journal of Cleaner Production, 16(15), 1699-1710. https://doi.org/10.1016/j. jclepro.2008.04.020

Shapira, P., Youtie, J., \& Porter, A. L. (2010). The emergence of social science research on nanotechnology. Scientometrics, 85(2), 595-611. https://doi.org/10.1007/s11192-010-0204-X

Shwayri, S. T. (2013). A model Korean ubiquitous Eco-city? The politics of making Songdo. Journal of Urban Technology, 20(2), 39-55. https://doi.org/10.1080/10630732.2012.735409

Tateishi, E. (2018). Craving gains and claiming "green" by cutting greens? An exploratory analysis of greenfield housing developments in Iskandar Malaysia. Journal of Urban Affairs, 40(3), 370-393. https://doi.org/10.1080/07352166.2017.1355667

Tranfield, D., Denyer, D., \& Smart, P. (2003). Towards a methodology for developing evidence-informed management knowledge by means of systematic review. British Journal of Management, 14(3), 207222. https://doi.org/10.1111/1467-8551.

Treinta, F. T., Farias Filho, J. R., Sant'Anna, A. P., \& Rabelo, L. M. (2014). Metodologia de pesquisa bibliográfica com a utilização de método multicritério de apoio à decisão. Production, 24(3), 508-520. https://doi.org/10.1590/S0103-65132013005000078

UE. (2021). Urban Development, European Commission, European Union (EU) regional and urban development, Regional Policy. Retrieved February 10, 2021, from https://ec.europa.eu/regional_policy/pt/ policy/themes/urban-development/

UN. (2019). Revision of World Population Prospects, the United Nations. Retrieved February 25, 2020, from https://population.un.org/wpp/.

UN-Habitat (2016). World Cities Report 2016. Urbanization and Development: Emerging Futures. United Nations Human Settlements Programme. https://unhabitat.org/wp-content/uploads/2014/03/WCR-\% 20Full-Report-2016.pdf. (n.d.).

Vakula, M. A., Guseva, T. V., Tikhonova, I. O., Molchanova, Y. P., \& Schelchkov, K. A. (2018). Green and Resilient City: Obligatory requirements and voluntary actions. Smart and sustainable cities conference (pp. 249-268). Springer.

van Dijk, M. P., \& Zhang, M. (2019). Urban water management paradigms in Chinese cities. Sustainability (switzerland), 11(11), 1-14. https://doi.org/10.3390/su11113001

Vanolo, A. (2014). Smartmentality: The smart city as disciplinary strategy. Urban Studies, 51(5), 883-898. https://doi.org/10.1177/0042098013494427

Visser, R. (2019). Posthuman policies for creative, smart, eco-cities? Case studies from China. Environment and Planning A, 51(1), 206-225. https://doi.org/10.1177/0308518X18765481 
Wachsmuth, D., Cohen, D. A., \& Angelo, H. (2016). Expand the frontiers of urban sustainability. Nature, 536(7617), 391-393. https://doi.org/10.1038/536391a

Wasserman, S., \& Faust, K. (1994). Social network analysis: Methods and applications. Cambridge University Press, 1, 116. https://doi.org/10.1525/ae.1997.24.1.219

Watson, V. (2014). African urban fantasies: Dreams or nightmares? Environment and Urbanization, 26(1), 215-231. https://doi.org/10.1177/0956247813513705

White, H. D., \& Griffith, B. C. (1981). Author cocitation: A literature measure of intellectual structure. Journal of the American Society for Information Science, 32(3), 163-171. https://doi.org/10.1002/asi. 4630320302

Wong, T. C., \& Yuen, B. (2011). Eco-city planning Policies, practice and design. Springer Science+ Business Media.

Wu, F. (2020). Adding new narratives to the urban imagination: An introduction to 'New directions of urban studies in China.' Urban Studies, 57(3), 459-472. https://doi.org/10.1177/0042098019898137

Xiao, Y., \& Watson, M. (2019). Guidance on conducting a systematic literature review. Journal of Planning Education and Research, 39(1), 93-112. https://doi.org/10.1177/0739456X17723971

Xie, L., Cheshmehzangi, A., Tan-Mullins, M., Flynn, A., \& Heath, T. (2020). Urban entrepreneurialism and sustainable development: A comparative analysis of Chinese Eco-developments. Journal of Urban Technology, 27(1), 3-26. https://doi.org/10.1080/10630732.2019.1680940

$\mathrm{Xu}$, J. (2017). Bargaining for nature: Treating the environment in China's urban planning practice. Urban Geography, 38(5), 687-707. https://doi.org/10.1080/02723638.2016.1139414

Yigitcanlar, T. (2015). Smart cities: An effective urban development and management model? Australian Planner, 52(1), 27-34. https://doi.org/10.1080/07293682.2015.1019752

Yigitcanlar, T., \& Lee, S. H. (2014). Korean ubiquitous-eco-city: A smart-sustainable urban form or a branding hoax? Technological Forecasting and Social Change, 89, 100-114. https://doi.org/10. 1016/j.techfore.2013.08.034

Zhuang, Y. (2015). Confucian ecological vision and the Chinese eco-city. Cities, 45, 142-147. https://doi. org/10.1016/j.cities.2015.03.004

Zweig, M. H., \& Campbell, G. (1993). Receiver-operating characteristic (ROC) plots: A fundamental evaluation tool in clinical medicine. Clinical Chemistry, 39(4), 561-577. https://doi.org/10.1093/clinchem/ 39.4.561

Publisher's Note Springer Nature remains neutral with regard to jurisdictional claims in published maps and institutional affiliations. 